\title{
Sundhedsplatformen i modvind: En analyse af aktørernes teknologiforståelser i danske medier
} Af Ulrik Bisgaard Ulsrod Røhl og Jeppe Agger Nielsen *)

\section{Resumé}

Sundhedsplatformen udgør et af de mest omdiskuterede offentlige digitaliseringsinitiativer i de senere år i Danmark og Skandinavien. Artiklen zoomer ind på, hvordan Sundhedsplatformen fremstilles i den offentlige debat baseret på en undersøgelse af 520 nyhedsartikler i danske medier i perioden 2012-2018. Artiklen belyser de forskellige interessenters (læger, politikere m.fl.) opfattelser og forståelser af Sundhedsplatformen ("technological frames"), ligesom det belyses, hvordan journalister og redaktører fremstiller ("vinkler") muligheder og problemer ved anvendelse af Sundhedsplatformen. Samlet er de kritiske udsagn om Sundhedsplatformen tydeligt fremherskende og baseret på grundlæggende opfattelser af, at Sundhedsplatformen begrænser arbejdsglæden, medfører usikker patientbehandling, og fortrænger menneskeligheden i mødet mellem patient og personale. Debatten er samtidig karakteriseret ved en kraftig skævhed, i hvilke interessenter som kommer til orde med læger som den dominerende interessentgruppe, der går forrest i den til tider heftige kritik. Artiklen bidrager med indgående viden om, hvordan Sundhedsplatformens formål, implementering og brug opfattes af centrale interessenter i sundhedsvæsenet, og viser hvordan indførelse af et omfattende og avanceret IT-system i offentlige organisationer kan blive et omdrejningspunkt i medierne.

\section{Nøgleord}

Sundhedsplatformen; elektronisk patientjournal (EPJ); implementering; medieanalyse; teknologiske forståelsesrammer

*) Ulrik Bisgaard Ulsrod Røhl er ph.d.-stipendiat og Jeppe Agger Nielsen er ph.d. og professor (mso) - begge ved Institut for Statskundskab på Aalborg Universitet. 


\section{A. Introduktion}

\section{Baggrund}

Moderniseringen af den danske offentlige sektor gennem digitalisering er i stigende grad blevet gjort til genstand for politisk og offentlig debat (Nielsen, Mathiassen \& Newell, 2014; Ejersbo \& Greve, 2016, Schou \& Hjelholt, 2019). Et af tidens mest omdiskuterede initiativer er indførelsen af den omfattende it-løsning, Sundhedsplatformen, i de to sjællandske regioner, Region Hovedstaden og Region Sjælland. I medierne er Sundhedsplatformen blevet omtalt som en offentlig ITskandale, fx 'Skandalen om Sundhedsportalen er et studie i ringe planlægning”' (Information, 22. juni 2018) og "Sundhedsplatformen kostede Region Sjælland 700 millioner" (Computerworld, 7. juni 2018). Politisk er Sundhedsplatformen - og ikke mindst de oplevede implementeringsproblemer - blevet inddraget i regionale og landsdækkende debatter, og senest knyttet til Regeringen Lars Løkke Rasmussen III's forslag til en gennemgribende sundhedsreform forud for folketingsvalget i juni 2019. Medlemmer af flere daværende regeringspartier har i pressen fremlagt problemer med Sundhedsplatformen som en del af baggrunden for forslaget om Sundhedsreformen (Berlingske Tidende, 23. januar 2019).

På den ene side er den store interesse for Sundhedsplatformen overraskende. Overraskende fordi Sundhedsplatformen i sin kerne er et IT-system til understøttelse af operationelle funktioner på regionernes hospitaler som fx medicinering og operationsbooking (Region Hovedstaden, 2019a). Systemet har således ikke direkte relevans for mere traditionelle sundhedspolitiske emner som adgang, ventelister, prioritering og finansiering. Omvendt er interessen ikke overraskende, fordi Sundhedsplatformen formodentlig er danmarkshistoriens største it-projekt på sundhedsområdet omfattende en række hospitaler og psykiatrifunktioner. Hertil kommer, at Sundhedsplatformen har betydet forandring af en række arbejdsgange, herunder angiveligt øgede administrative opgaver for visse lægegrupper.

Forskningsmæssigt er der en spirende interesse for Sundhedsplatformen, men indtil nu findes der alene få udgivelser om Sundhedsplatformen og brugen heraf. Et par artikler beskæftiger sig med ændringer i det sundhedsfaglige arbejde i form af dokumentation, sekretærarbejde og patientinvolvering, som Sundhedsplatformen inden implementeringen forventedes at medføre (Mørck et al., 2018; Brorholt, 2016). Simonsen et al. (2018) fremhæver i forbindelse med en belysning af kvalitetssikring i sundhedssektoren Sundhedsplatformen som et eksempel på store teknologi-investeringer på sundhedsområdet, som "dramatisk" forandrer organiseringen af 
arbejdet, og hvordan organiseringen tilsvarende påvirker teknologien. Endelig omtales Sundhedsplatformen i et par arbejdspapirer: Bossen (2018) beskæftiger sig kortfattet med, hvordan implementeringen af Sundhedsplatformen forekommer at påvirke ikke bare organiseringen af arbejdet, men også rekrutteringsbehov, afskedigelser og videreuddannelse i de to regioner. Som del af en bredere analyse af store, offentlige it-projekter i Danmark noterer Lauesen (2018), at implementeringen af Sundplatformen ser ud til at have fulgt budget og planlagt tidsplan, mens de planlagte forretningsgevinster endnu ikke har indfundet sig.

\section{Artiklens formål}

Ærindet i denne artikel er at belyse, hvordan Sundhedsplatformen er blevet debatteret i offentligheden med særlig fokus på, hvordan centrale interessentgrupper (læger, sygeplejersker, politikere mv.) udtrykker sig om Sundhedsplatformen. Samtidig belyses hvilke interessentgrupper, som i særlig grad er kommet til orde, og dermed har haft særlig mulighed for at præge debatten. Artiklen bygger på analyse af 520 artikler om Sundhedsplatformen i fem landsdækkende aviser over en $6 \frac{1}{2}$ årig-periode frem til udgangen af 2018 . Artiklen belyser ikke de eventuelle gevinster og problemer, der ér ved anvendelsen af Sundhedsplatformen i de to regioner - det kræver studier af den direkte anvendelse af systemet på hospitalerne. Til gengæld belyser artiklen de opfattelser og bagvedliggende forståelser af Sundhedsplatformen, som er kommet til udtryk i den offentlige debat guidet af følgende forskningsspørgsmål: Hvilke interessenter og telnologi-forståelser dominerer debatten om Sundhedsplatformen, og hvordan fremstilles muligheder og problemer ved anvendelse af platformen $i$ medierne?

Artiklen udgør den første større videnskabelige analyse af indførelsen af Sundhedsplatformen, og bidrager til en øget forståelse af, hvordan Sundhedsplatformen og de medfølgende implementeringsproblemer opfattes af centrale interessenter i sundhedsvæsenet, samt hvordan indførelse af digital teknologi i store, offentlige organisationer, som fx hospitalsvæsenet, kan blive et omdrejningspunkt i medierne. Dermed kaster artiklen også indirekte lys på det formodede feedback-loop fra omfattende medieomtale af en it-løsning til brugergruppers opfattelser af selvsamme it-løsninger. Den bagvedliggende antagelse ér, at en øget forståelse af de forskelligartede opfattelser, der knytter sig til Sundhedsplatformen, giver bedre muligheden for at håndtere disse, og dermed styrke potentialet for at udnytte teknologien til reel værdiskabelse i de organisationer, som ibrugtager den (Orlikowski \& Gash, 1994). 


\section{B. Baggrund: Sundhedsplatformen i Region Hovedstaden og Region Sjælland}

"Sundhedsplatformen" er det officielle navn for den sammenhængende, kliniske og administrative it-løsning, som Region Hovedstaden og Region Sjælland tog i brug på alle somatiske og psykiatriske hospitalsenheder i de to regioner fra maj 2016 til november 2017.

Sundhedsplatformen erstattede ved sin indførsel op mod 30 tidligere it-systemer og samlede de funktioner, som læger, sygeplejersker og andre medarbejderne bruger ofte, herunder medicinering, dokumentation, stuegang, operationsbooking og bestilling af laboratorieprøver. Herudover giver Sundhedsplatformen patienterne forskellige muligheder for at følge egen behandling via den såkaldte "Min Sundhedsplatform”, som er tilgængelig via web og via app (Region Hovedstaden, 2019a).

Sundhedsplatformen er udviklet og leveres til de to regioner af den amerikanske, sundheds-itleverandør, Epic, i samarbejde med den danske it-leverandør, NNIT. Epic er en global leverandør af sundheds-it, og EPJ-systemet, som ligger bag Sundhedsplatformen, bruges på ca. 1.100 hospitaler verden over og servicerer ca. 175 millioner patienter (Region Hovedstaden, 2016). Sundhedsplatformen har ca. 50.000 medarbejdere som brugere på omkring 70 hospitaler og institutioner og dækker et patientgrundlag på ca. 2,5 mio. indbyggere (Konkurrence- og Forbrugerstyrelsen, 2012). Implementeringen af Sundhedsplatformen i de to regioner er ofte blevet kaldt danmarkshistoriens største sundheds-it-projekt repræsenterende en investering i de to regioner på samlet set min. 3,0 mia. kr. (Region Hovedstaden, 2015: 3).

Der findes flere forskellige såkaldte 'maturity'-modeller på området for sundheds-it, som forsøger at måle modenheden i hospitalers it-anvendelse (Carvalho, Rocha \& Abreu, 2016). For at forstå omfanget og kompleksiteten i Sundhedsplatformen er det relevant at notere sig, at ambitionen med Sundhedsplatformen var at løfte samtlige hospitaler i de to regioner til det øverste, mest avancerede, niveau i den såkaldte 'Electronic Medical Record Adoption Model' fra det amerikanske konsulentfirma HIMSS Analytics (Konkurrence- og Forbrugerstyrelsen, 2012). Det øverste niveau beskriver hospitaler, som fungerer fuldt papirløse baseret på en elektronisk patientjournal (EPJ), og hvor alle patientdata kan deles med eksterne behandlingsenheder elektronisk og sikkert. Omfanget af den planlagte omstilling, som hospitalerne skulle gennemgå i forbindelse med overgangen til Sundhedsplatformen, er ganske omfattende, og inkluderede ændringer i arbejdsgange og vaner i form af fx lægers øgede registrering af patientoplysninger og tilsvarende mindre brug af lægesekretærer (Region Hovedstaden, 2019b, og Simonsen, 2018: 50). 
Ambitionerne med Sundhedsplatformen har altså fra starten været høje, og platformen skulle samlet gøre det lettere at være både patient, klinisk medarbejder og leder i de to regioner gennem (a) én fælles elektronisk patientjournal, som både patienter og klinikere har adgang til; (b) samlede patientinformationer, der giver overblik og nem adgang på tværs af hospitaler, institutioner og afdelinger; og (c) understøtte tidstro og papirløse arbejdsgange på hospitalerne. Besparelserne kunne ifølge regionernes beregninger omsættes til 770 - 1.245 mio. kr. pr. år, når platformen er taget fuldt i drift og implementeringen overstået efter fire år (Region Hovedstaden, 2015: 2 og Region Sjælland, 2014: 1-2).

Udrulning af Sundhedsplatformen - forstået som den praktiske ubrugtagning på det enkelte hospital mv. - blev gennemført over en periode på 18 måneder fra maj 2016 til november 2017 baseret på fem grupper af hospitalsenheder. Sundhedsplatformen blev først taget i brug på Herlev og Gentofte Hospital i Region Hovedstaden, og afslutningsvist ibrugtaget på samtlige hospitaler og psykiatriske institutioner i Region Sjælland i november 2017. Et grafisk overblik over udrulningen fremgår af Figur 3 nedenfor.

Som vi går i detaljer med i artiklens afsnit $\mathrm{D}$, har der været væsentlig kritik af anvendelsen af Sundhedsplatformen i medierne. Baseret på vores analyse forekommer problemerne samlet set især at have præget anvendelsen af Sundhedsplatformen i Region Hovedstaden, da den senere implementering i Region Sjælland gav mulighed for at forbedre systemet og den tilhørende uddannelse baseret på erfaringer fra de første udrulningsgrupper.

Baseret på oplysninger fra Sundheds- og Ældreministeriet og Rigsrevision kan problemerne overordnet set opdeles i fem områder, som alle er delvist beslægtede (Sundheds- og Ældreministeriet, 2017 og Rigsrevisionen, 2017): (a) Ibrugtagningen af Sundhedsplatformen har givet anledning til et væsentlig kraftigere fald i hospitalernes aktiviteter, og dermed også et væsentlig kraftigere fald i indberetningerne til det statslige Landspatientregister (LPR), end antaget på forhånd. Desuden er der indikationer på, at der flere steder har været 'huller' i indberetningerne, således at ikke alle aktiviteter er blevet indberettet. Dette problem har flere konsekvenser, herunder at tvivl om hvorvidt krav til fx kræftbehandlinger er blevet overholdt, og at regionernes økonomi påvirkes betragteligt; (b) Problemer med sammenhængen (integrationer mv.) til det statslige Fælles Medicinkort (FMK), som samler ordineringer af medicin. Derved er der opstået risiko for fejl, dobbeltordinationer mv. af medicin; (c) Uddannelse af de kommende 
brugere af Sundhedsplatformen har været utilstrækkelig, og er delvist sket i en ufærdig version af platformen, som ikke var identisk med den medarbejderne efterfølgende tog i brug; (d) Anvendelsen af Sundhedsplatformen er præget af manglende brugervenlighed bl.a. i form af unødigt mange "klik", samt at testen af platformens brugervenlighed ikke var tilstrækkelig inden ibrugtagningen; (e) Udviklingen og tilpasningen af platformen var forsinket op til ibrugtagningen, og den blev derfor taget i brug med en række fejl og mangler, som bl.a. gjorde det vanskeligt at registrere aktiviteter.

Rigsrevisionen tog i 2017 initiativ til en undersøgelse af Region Hovedstadens forberedelse og ibrugtagning af Sundhedsplatformen (undersøgelsen omfattede alene implementeringen i den første udrulningsgruppe bestående af Herlev og Gentofte Hospital). I den efterfølgende beretning formulerer statsrevisorerne en kraftig kritik af regionen: "Region Hovedstadens forberedelse af ibrugtagningen af Sundhedsplatformen på Herlev og Gentofte Hospital har været uprofessionel og kritisabel.” Det hedder videre, at ”... faldet i hospitalernes aktivitet har været væsentligt over det forventede, og at de forudsatte gevinster ved Sundhedsplatformen endnu ikke har kunnet realiseres.” (Rigsrevisionen, 2017: Statsrevisorernes bemærkning).

Sundhedsplatformen er efter den første ibrugtagning på Herlev og Gentofte Hospital løbende blevet forbedret og udvidet funktionalitetsmæssigt. Desuden har det - som beskrevet ovenfor været muligt for de to regioner at tilpasse uddannelsen af brugere baseret på de erfaringer, som blev gjort indledningsvist. I marts 2018 gennemførte Region Hovedstaden en undersøgelse af medarbejdernes tilfredshed med Sundhedsplatformen: $27 \%$ af brugerne var samlet set tilfredse, 40 $\%$ er utilfredse, og $32 \%$ er hverken er tilfredse eller utilfredse (undersøgelsens svarprocent var $38,2 \%$ ). Undersøgelsen viser, at medarbejderne oplever, at systemet er hurtigt og stabilt, imens især brugervenligheden halter (Region Hovedstaden, 2018).

\section{Metode}

Som nævnt indledningsvist er ambitionen med denne artikel at belyse, hvilke interessenter og teknologiforståelser, som har domineret debatten om Sundhedsplatformen. 


\section{Forskningsdesign}

Artiklen bygger på en kvantitativ (hvor mange, hvem) og kvalitativ (hvad, hvordan) indholdsanalyse af interessenters udsagn om Sundhedsplatformen i skrevne, danske, landsdækkende medier over $6 \frac{1}{2}$ år frem til udgangen af 2018. Artiklen er således både en analyse af de interessenter og forståelser, som har domineret debatten, og samtidig en analyse af mediernes gengivelse og prioritering af de forskellige forståelser. Det er velkendt, at medierne via beslutninger om hvad og hvordan stof dækkes - ikke bare gengiver omverdenen, men også deltager i skabelsen af dagsordener (Lund, 1997; Clayman \& Reisner, 1998). Udsagn om Sundhedsplatformen i medierne er derfor et stærkt udgangspunkt for at belyse de forståelser, som præger debatten om Sundhedsplatformen.

Vi har analyseret artikler i fem toneangivende dagblade; Berlingske Tidende, Børsen ${ }^{1}$, Information, Jyllands-Posten og Politiken. I udvælgelsen af medier har vi søgt at opnå en politisk balance således at medierne repræsenterer et centrum-venstre og et centrum-højre perspektiv. Der er ikke medtaget artikler fra medier repræsenterende de egentlige politiske yderfløje, ligesom der ikke er medtaget omtale i elektroniske medier. Desuden er undersøgelsen ikke geografisk afgrænset til de to regioner - Region Hovedstaden og Region Sjælland - som har ibrugtaget Sundhedsplatformen, men omfatter i stedet udsagn fra interessenter i hele landet, idet debatten primært har været en landspolitisk frem for lokalpolitisk debat. Debatten er således bl.a. præget af udsagn fra politikere fra både andre regioner og fra landspolitikere.

\section{Datamateriale}

Studiet tager afsæt i en analyse af 652 artikler fra de nævnte aviser, som omtaler Sundhedsplatformen i perioden 1. juli 2012 til 31. december 2018. Som nævnt i afsnit Bo blev Sundhedsplatformen ibrugtaget på det første hospital i maj 2016, og artiklerne omfatter således både en længere periode før og efter ibrugtagningen af Sundhedsplatformen.

Artiklerne er udvalgt baseret på en søgning i Infomedias 'Mediearkiv'-database, som dækker langt de fleste aviser i Danmark, herunder de fem nævnte. I søgningen har vi bestræbt os på at identificere alle potentielt relevante artikler, hvorfor der er anvendt brede søgekriterier: Vi har søgt på 'Sundhedsplatformen' men også på 'Epic' (hovedleverandøren af Sundhedsplatformen), 'itsystem', 'it-platform' og 'it-løsning' i sammenhæng med 'region’2. Af de 652 identificerede artikler 
er det 520 artikler, som indeholder egentlig omtale af Sundhedsplatformen, og 246 artikler med udsagn fra interessenter (jf. senere). Endelig omfatter datasættet også artikler bragt i flere aviser, som er stort set identiske og baseret på fx materiale fra Ritzau, idet disse er udtryk for sideløbende gengivelse og prioritering i flere medier, jf. afsnit $\mathrm{C} 1$.

Som det fremgår af Figur 1 er antallet af artikler ikke ligeligt fordelt mellem de undersøgte aviser. Det er således Politiken, som har bragt flest artikler, hvilket formodentlig bl.a. kan forklares med deres overvejende geografiske fokus på København og Sjælland, samt en formodet, traditionel læserskare blandt offentlig ansatte.

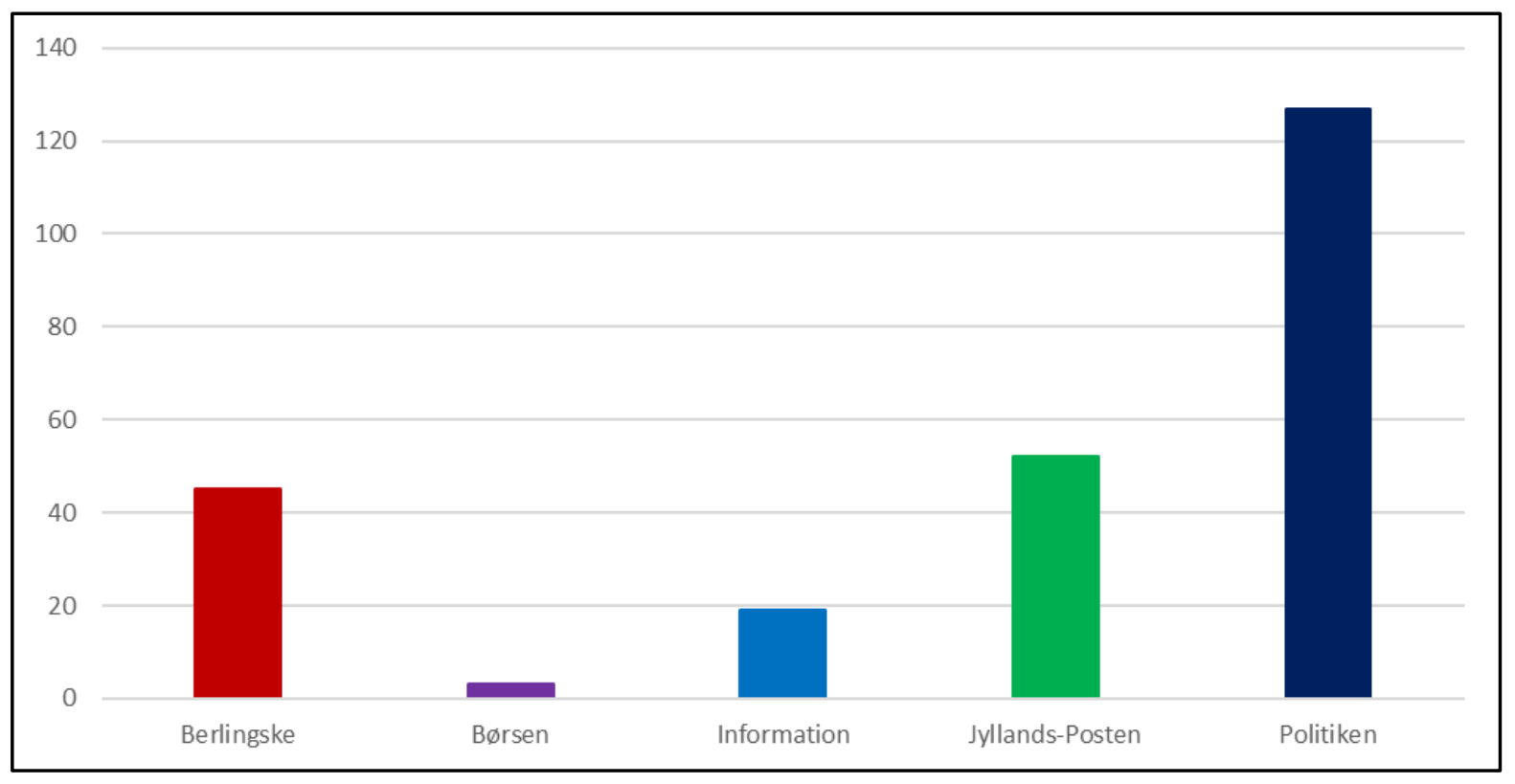

Figur 1: Artikler med udsagn fra interessenter fordelt på aviser; lodret akse angiver antal artikler $(N=246)$

I forhold til den ønskede belysning af undersøgelsesspørgsmålet er det en metodisk begrænsning, at data ikke omfatter materiale fra elektroniske medier, som fx DR1, DR2, TV-2, TV-2 News, P1 og Radio 24/7. Dette materiale er udeladt af praktiske hensyn, idet en søgning og analyse af udsagn i de skrevne medier er mindre ressourcekrævende at gennemføre. Desuden vurderes det, at markante udsagn bragt i de nævnte elektroniske medier i et stort omfang vil være blevet gengivet i de analyserede skrevne medier, og derfor alligevel fremgå af det analyserede materiale. Det er ligeledes en begrænsning, at specialiserede tidsskrifter som Ugeskrift for Læger, Dagens Medicin, Altinget Sundhed og Mandag Morgen ikke er inkluderet i analysen. En analyse af artikler om 
Sundhedsplatformen i disse medier kunne have givet yderligere nuancer til forståelsen af muligheder og problemer ved Sundhedsplatformen.

\section{Data-analyse}

Som nævnt er der gennemført en kvantitativ og kvalitativ indholdsanalyse af de udvalgte artikler: I første omgang er hver enkel artikel vurderet i forhold til, hvorvidt artiklen indeholder udsagn om Sundhedsplatformen fra en eller flere interessenter. Med udsagn menes formuleringer, som er tydeligt knyttet til en interessent, og som indeholder stillingtagen til Sundhedsplatformen, og som indgår i både almindelige artikler, læserbreve og kommentarer. Artikler, som alene indeholder en tilstræbt neutral nyhedsformidling ang. platformen og ikke indeholder citater eller lign. fra interessenter, er således ikke medtaget. Som det fremgår af Figur 2 er der 246 artikler i perioden, som indeholder udsagn fra en eller flere interessenter om Sundhedsplatformen.

Den samme artikel kan indeholde udsagn fra flere interessenter, og kan derfor optræde flere gange i den nedenstående analyse. Flere udsagn fra samme interessent i samme artikel er alene kodet én gang. Desuden er udsagn fra journalister, når disse optræder som nyhedskommentatorer eller lign., og udsagnet indeholder en tydelig holdning, medtaget som et udsagn fra en interessent. Den anvendte analyseenhed er altså udsagn om Sundhedsplatformen fra én interessent, som er kodet for mening. I alt er der analyseret - kodet - 291 udsagn.

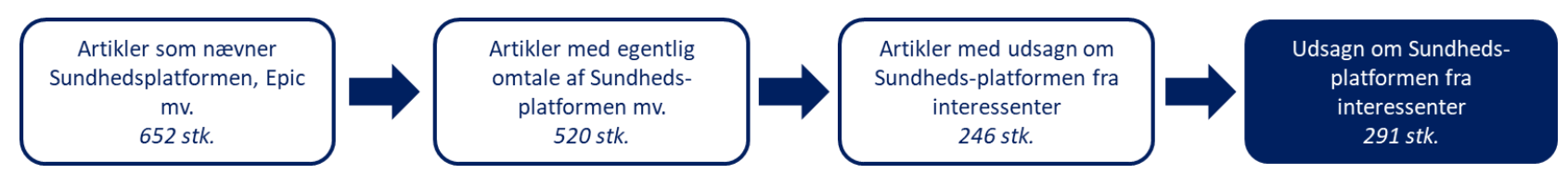

Figur 2: Oversigt over analyseprocessen og antal analyserede artikler og interesseudsagn

Som næste skridt i kodningsarbejdet blev udsagnene kodet strukturelt i henhold til, hvilken type interessent, som formulerede udsagnet (Bernard et al., 2017: 126 \& 249). I alt er der anvendt 10 prædefinerede kategorier, som beskriver interessenter (jf. Tabel 1), som dækker bredt fra bl.a. patienter over politikere og fagpersonale til journalister. Kode D ('Statslige / nationale aktører (styrelser mv.)') dækker udsagn fra embedsmænd tilknyttet statslige styrelser, ligesom enkelte udsagn fra bl.a. Rigsrevisionen er medtaget her. Kode H ('It-leverandører') dækker både repræsentanter for leverandøren af Sundhedsplatformen, det amerikanske firma Epic, og andre interessenter med tilknytning til it-branchen. Kode $\mathbf{J}$ ('Andre') dækker udsagn fra interessenter som bl.a. privatpersoner (som ikke vurderes at være patienter) og forskere. For flere af koderne 
gælder det, at der er medtaget udsagn fra både individer (fx en overlæge) og fra organisationer repræsenterende den specifikke type interessent (fx Praktiserende Lægers Organisation, PLO).

Fjerde del af kodningen, som er den mest omfattende, bygger primært på en tematisk, latent kodning (Bernard et al., 2017:126 \& 249) baseret på fortolkning af udsagnene i henhold til interessenternes teknologiforståelse. Vurderingen af teknologiforståelse er foretaget med udgangspunkt i Orlikowskis \& Gashs (1994) veletablerede og ofte anvendte typologi for teknologiske forståelsesrammer (se fx Nielsen, Andersen \& Sigh, 2016 og Young, Mathiassen \& Davidson, 2016), som beskriver henholdsvis aktørers forståelse af (a) teknologiens grundlæggende natur ('nature'), (b) teknologiens formål ('strategy') og (c) teknologiens anvendelse ('use'). ${ }^{3}$ Vores operationalisering af de tre begreber i forhold til Sundhedsplatformen fremgår af Tabel 1.

Vi har anvendt en kombination af præ-definerede (deduktive) og empiri-drevne (induktive) koder. Som det fremgår af Tabel 1 er der for temaerne 'formål med Sundhedsplatformen' og 'Sundhedsplatformens grundlæggende natur' etableret koder baseret på en indledende identificering af sub-temaer i henholdsvis fem og seks kategorier. Betydningen af koderne udfoldes i det følgende afsnit $\mathrm{D}^{4}$.

Når det gælder 'anvendelse af Sundhedsplatformen' har vi kodet interesseudsagnene i fire kodekategorier; (a) positiv omtale (b) negativ omtale, (c) både positiv og negativ omtale og (d) hverken positiv eller negativ omtale (neutral, beskrivende). ${ }^{5}$ Vi har også - i lyset af den overvejende negative vurdering af Sundhedsplatformens anvendelse - ledt efter årsager hertil, og kodet efter om den negative vurdering knytter sig til (a) selve IT-løsningen, (b) implementeringen, (c) regionsledelsen eller (d) brugerne af systemet. Hermed knytter vi an til spørgsmålet om, hvorvidt de hidtidige problemer med Sundhedsplatformen repræsenterer en implementeringsfejl (som kan udbedres ved at øge undervisningsindsats mv.) eller om det snarere er udtryk for nogle grundlæggende mangler ved IT-løsningen, som kan vanskeliggøre, at platformen nogensinde kommer til at fungere adækvat.

Kodningen er registreret i Microsoft Excel og foretaget af 1. forfatteren med assistance fra en studentermedhjælp ${ }^{6}$. For at kvalitetssikre kodningsarbejdet er der gennemført en indledende, fælles kodning af udvalgte udsagn, ligesom tvivl efterfølgende er afklaret og kodet i fællesskab med 2 . forfatteren. 


\begin{tabular}{|c|c|c|c|c|}
\hline Tema & Beskrivelse & Ko & & Type \\
\hline Interessenter & $\begin{array}{l}\text { Interessent-grupper, } \\
\text { som formulerer } \\
\text { udsagnet }\end{array}$ & $\begin{array}{l}\text { A. } \\
\text { B. } \\
\text { C. } \\
\text { D. } \\
\text { E. } \\
\text { F. } \\
\text { G. } \\
\text { H. } \\
\text { I. } \\
\text { J. }\end{array}$ & $\begin{array}{l}\text { Patienter (inkl.organisationer) } \\
\text { Politikere (Region Sjælland og } \\
\text { Region Hovedstad samt nationale) } \\
\text { Regionale embedsmænd } \\
\text { Nationale / statslige aktører } \\
\text { (styrelser mv.) } \\
\text { Sygeplejersker (inkl. organisationer) } \\
\text { Læger (inkl. organisationer) } \\
\text { Øvrigt sundhedsfagligt personale } \\
\text { (inkl. organisationer) } \\
\text { It-leverandører (Epic, NNIT, } \\
\text { konsulenthuse mv.) } \\
\text { Journalister, kommentatorer mv. } \\
\text { Andre }\end{array}$ & $\begin{array}{l}\text { Præ- } \\
\text { defineret }\end{array}$ \\
\hline $\begin{array}{l}\text { Grundlæggende } \\
\text { syn }\end{array}$ & $\begin{array}{l}\text { Opfattelse af } \\
\text { Sundhedsplatformens } \\
\text { grundlæggende } \\
\text { natur }\end{array}$ & $\begin{array}{l}\text { A. } \\
\text { B. } \\
\text { C. } \\
\text { D. } \\
\text { A. }\end{array}$ & $\begin{array}{l}\text { "Fremtidens hospital" } \\
\text { "Fortrænger menneskeligheden" } \\
\text { "Begrænser arbejdsglæden og stjæler } \\
\text { arbejdstiden" } \\
\text { "Usikker patientbehandling" } \\
\text { "Intet system er fejlfrit" }\end{array}$ & $\begin{array}{l}\text { Empiri- } \\
\text { drevet }\end{array}$ \\
\hline Formål & $\begin{array}{l}\text { Opfattelse af } \\
\text { formålet med } \\
\text { Sundhedsplatformens } \\
\text { anskaffelse og } \\
\text { implementering }\end{array}$ & $\begin{array}{l}\text { B. } \\
\text { C. } \\
\text { D. } \\
\text { E. } \\
\text { F. } \\
\text { G. }\end{array}$ & $\begin{array}{l}\text { Øget patient-involvering } \\
\text { Sammenhæng og patientsikkerhed } \\
\text { ”Et bedre og billigere it-system" } \\
\text { Effektivisering } \\
\text { ”Spare-øvelse" } \\
\text { Forbedret styring og videndeling }\end{array}$ & $\begin{array}{l}\text { Empiri- } \\
\text { drevet }\end{array}$ \\
\hline Anvendelse & $\begin{array}{l}\text { Opfattelse af den } \\
\text { faktiske anvendelse } \\
\text { af } \\
\text { Sundhedsplatformen }\end{array}$ & $\begin{array}{l}\text { A. } \\
\text { B. } \\
\text { C. } \\
\text { D. }\end{array}$ & $\begin{array}{l}\text { Positiv } \\
\text { Negativ } \\
\text { Både-og } \\
\text { Neutral }\end{array}$ & $\begin{array}{l}\text { Præ- } \\
\text { defineret }\end{array}$ \\
\hline Årsag & $\begin{array}{l}\text { Opfattelse af årsag til } \\
\text { negative eller både- } \\
\text { og vurdering af } \\
\text { Sundhedsplatformens } \\
\text { anvendelse }\end{array}$ & & $\begin{array}{l}\text { IT-løsning } \\
\text { Implementering } \\
\text { Regionsledelsen } \\
\text { Brugerne }\end{array}$ & $\begin{array}{l}\text { Præ- } \\
\text { defineret }\end{array}$ \\
\hline
\end{tabular}

Tabel 1: Oversigt over temaer og koder anvendt i indholdsanalysen; "Grundlaggende syn", "Formål" og "Anvendelse" er inspireret af Orlikowski $\Xi$ Gash (1994).

\section{Analyse: Sundhedsplatformen i medierne}

Sundhedsplatformen er blevet debatteret ivrigt i danske medier de senere år. Som vi viser nedenfor, er det primært læger, som har domineret debatten i medierne. Der tegner sig et billede 
af et implementeringsforløb med mange problemer, hvor kritiske udsagn om platformen er fremherskende. Som det fremgår af Figur 3 er det navnlig i 2017 og 2018, at Sundhedsplatformen finder spalteplads i aviserne, i takt med at platformen ibrugtages på først Herlev og Gentofte Hospital, og efterfølgende på øvrige hospitaler og institutioner i de to regioner.

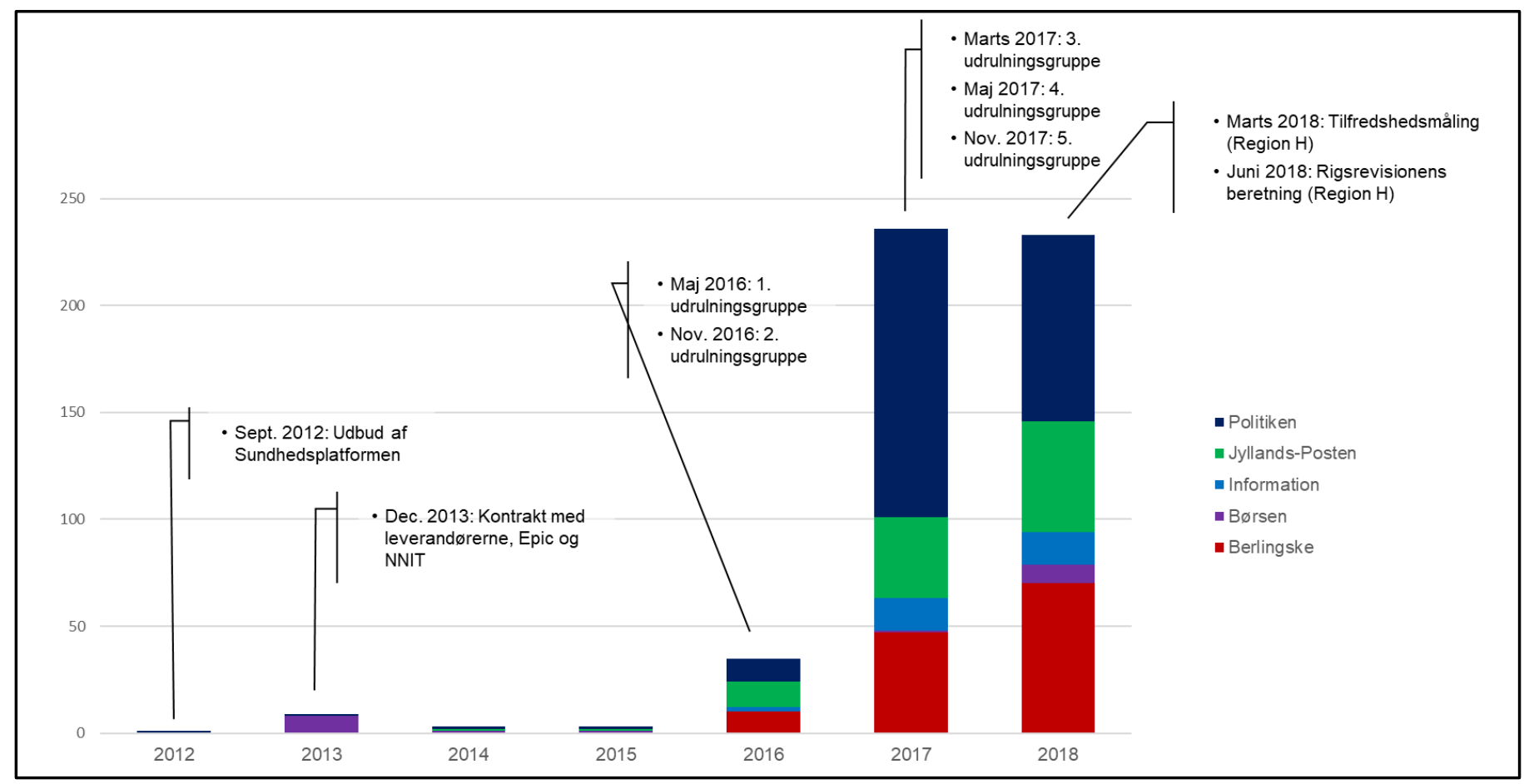

Figur 3: Fordeling af artikler med omtale af Sundhedsplatformen på medier samt oversigt over nøgle-begivenheder; lodret akse angiver antal artikler $(N=520)$.

Artiklerne før 2016 omhandler primært de to regioners fælles udbud af opgaven og de tilhørende erhvervsmæssige muligheder. Dækningen sker således også primært i erhvervsavisen Børsen. Overskrifter som ”Udskilningsløb om én milliard” (Børsen, 18. juni 2013) dominerer, mens en embedsmand fra Region Hovedstaden fortæller om den kommende Sundhedsplatform: "Formålet er at sikre en bedre og lettere hverdag for sundhedspersonalet, så de bedst muligt kan bruge deres tid og fokus på det, de er her for: At skabe højeffektiv og højkvalitetsbehandling af patienterne på landets hospitaler." (Politiken, 6. januar 2014)

Fra 2017 og fremefter vokser antallet af artikler kraftigt, og dækningen koncentreres om implementering og brug af Sundhedsplatformen med tydelig dominans af kritiske udsagn. Det er disse udsagn, som vi stiller skarpt på i det følgende. 


\section{Stemmer i debatten: Lægerne dominerer}

Som det ses i Figur 4, kommer en lang række interessenter til orde i medierne og ytrer sig om Sundhedsplatformen. Det gælder det sundhedsfaglige personale (læger, sygeplejersker mv.), politikere, embedsmænd og patienter. Vores opgørelse viser imidlertid også, at der er en markant forskel på, hvor meget de forskellige interessentgrupper kommer til orde.

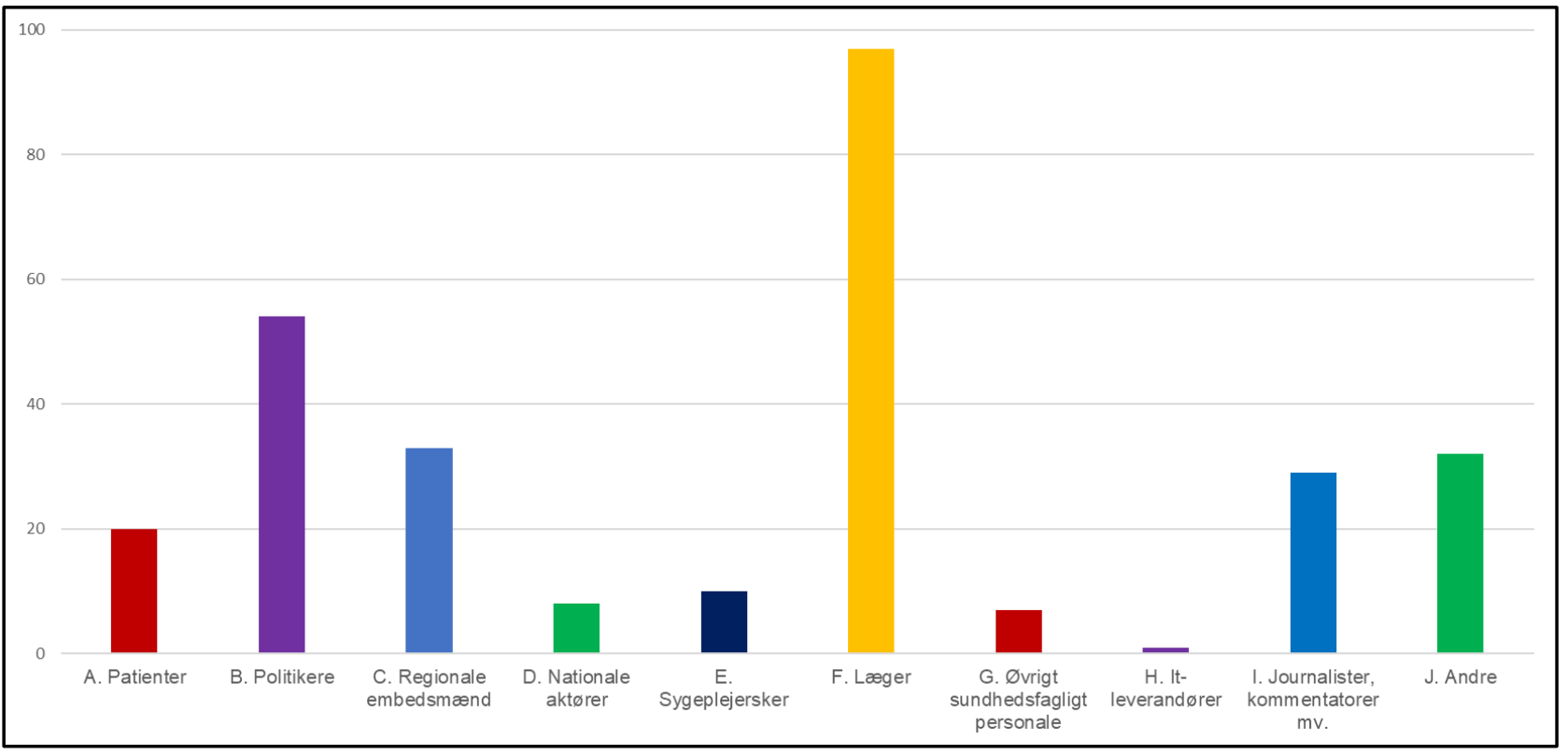

Figur 4 Fordeling af udsagn på interessent-type; lodret akse angiver antal udsagn $(N=291)$.

Som det fremgår af Figur 4, er det læger, som tegner sig for den største andel af interessantudsagnene: De står for mere end dobbelt så mange udsagn som de næste på listen (politikere). At lægerne udgør den dominerende aktørgruppe i debatten, er måske ikke så overraskende. Som en dominerende profession i sundhedssektoren får læger ofte taletid i medierne, og i og med at deres arbejde er direkte berørt af indførelsen af Sundhedsplatformen, er det oplagt, at de deltager ivrigt i debatten. Sygeplejergruppen, som også i dagligdagen benytter Sundhedsplatformen, indtager til gengæld en langt mindre synlig rolle i mediedebatten. Endelig er det også værd at bemærke, at andet sundhedsfagligt personale (kode G), herunder ikke mindst lægesekretærer - som har været direkte berørt af Sundhedsplatformen i form af afskedigelser tilsvarende er er kommet begrænset til orde i debatten.

Politikere (regionale som nationale) er til gengæld synlige i debatten og optræder som den interessentgruppe med næstflest udsagn. Selvom implementering af offentlige administrative IT- 
systemer ikke står øverst på den politiske dagsorden, er den markante tilstedeværelse formodentlig udtryk for, at Sundhedsplatformen i løbet af 2017 og navnlig 2018 blev en "varm kartoffel” i kølvandet på kritikken, der fulgte dens implementering. Som den tredje mest citerede gruppe er embedsmænd fra de to regioner. Som vi vil vise senere, er der interessante forskelle i udsagnene fra hhv. politikere og embedsmænd. Det er også værd at nævne, at repræsentanter for it-leverandører (Epic, NNIT mv.) stort set ikke optræder i debatten, til trods for at selve den tekniske løsning bliver udsat for væsentlig kritik. Der er med andre ord få tekniske eksperter, som har artikuleret synspunkter og er kommet til orde i de analyserede medier. Endelig skal det bemærkes, at række journalister tager del i debatten, ikke blot som journalistiske budbringere, men også som kommentatorer med selvstændige udsagn. Der er tale om en mindre kreds af kommentatorer, hvor særlig én kommentator fra Jyllands-Posten dominerer med 10 udsagn om Sundhedsplatformen svarende til ca. $5 \%$ af samtlige udsagn. Journalister og kommentatorer er således ikke blot betydende ift. kildeudvælgelse, vinkling og 'framing' mv. (Entman, 1993, og Hjarvard, 2015), men også en central, direkte stemme i debatten.

\section{Syn på formålet: Sundhedsplatformen som spare-øvelse står centralt}

Interessenternes syn på formålet med Sundhedsplatformen kan overordnet set opdeles i seks forskellige kategorier, jf. Tabel 1. Som det ses i Figur 5, er mange af de artikulerede formål, som vi finder i mediedebatten, i overensstemmelse med de officielle ambitioner, jf. afsnit B. Det gælder således de udsagn, som vi har sammenfattet under "Øget patient-involvering", "Sammenhæng og patientsikkerhed", "Et bedre og billigere it-system" og "Forbedret styring og videndeling". De nedenstående udsagn illustrerer disse formål:

Vi har fundet svaret på mange års udfordringer med usammenhangende systemer.

(politiker, Politiken, 20. maj 2016)

For skulle lager og sygeplejersker manøvrere rundt $i$ 3o it-systemer. Nu kan de nøjes med Sundhedsplatformen.

(erhvervskommentator, Jyllands Posten, 3. august 2016)

Målet er at få et bedre overblik og at inddrage patienterne, for eksempel ved at lage og patient sammen udfylder journalen

(læge, Information, 8. oktober 2016) 
Sundhedsplatformen bliver indfort for, atjeg og ikke mindst den lage, som skal behandle mig, har adgang til mine sundhedsdata

(læserbrevsskribent, Berlingske Tidende, 23. december 2016)

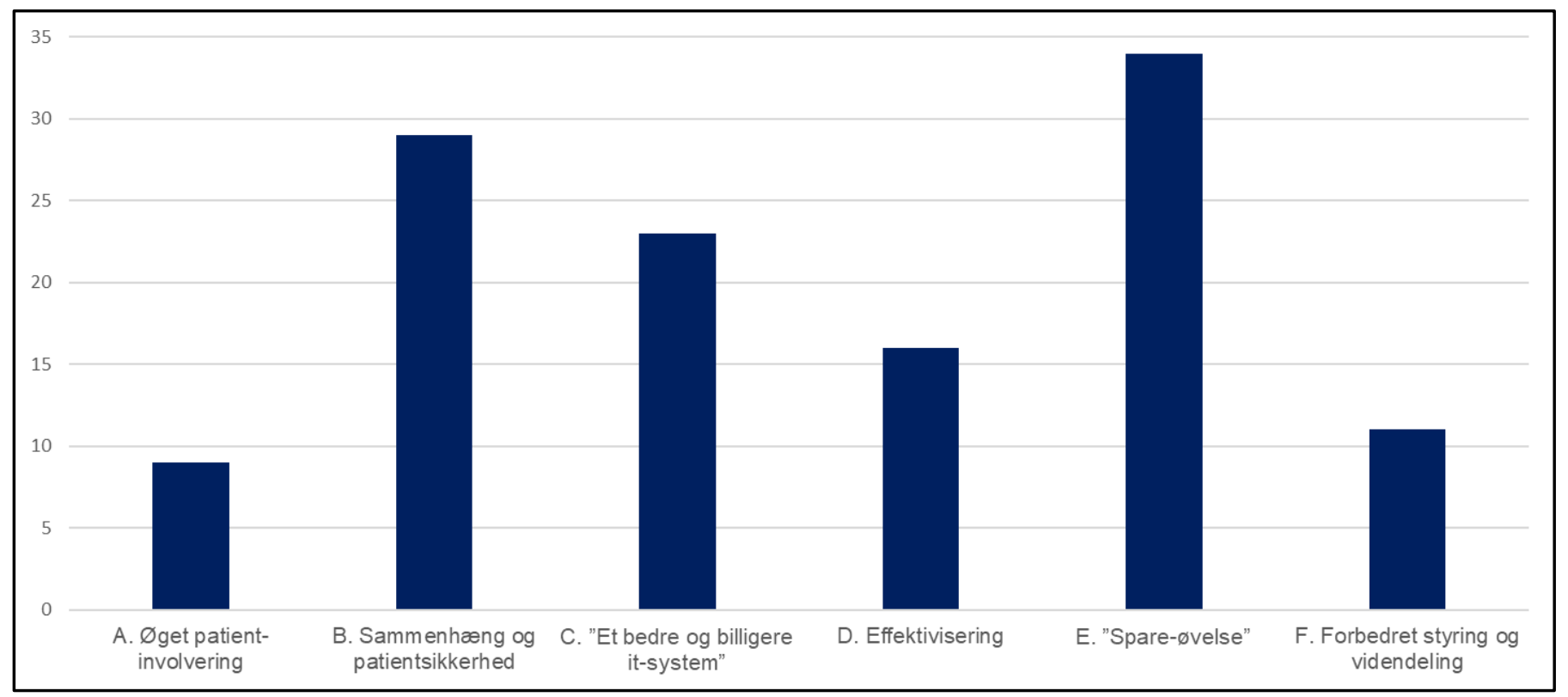

Figur 5: Udsagn ang. Sundhedsplatformens formål; lodret akse angiver antal udsagn $(N=122)$.

Når det er sagt, er "Spare-øvelse" imidlertid den oftest anførte begrundelse for indførelse af Sundhedsplatformen i vores analyse. Her er det vigtigt at forstå, at udsagn, som er kodet som denne begrundelse lægger vægt på, at der sideløbende med ibrugtagningen gennemføres usaglige budgetreduktioner, afskedigelser mv. på hospitaler og institutioner uden hensyn til de faktiske erfaringer med Sundhedsplatformen. Der ligger således en implicit, markant negativ vurdering af konteksten for Sundhedsplatformen bag sådanne udsagn. Omvendt er der også udsagn, som vægter "Effektivisering” som det primære formål - i modsætning til udsagn kodet som ”Spareøvelse" indeholder disse udsagn både implicitte positive og negative vurderinger af Sundhedsplatformen, og indikerer ikke en vurdering af formålet med Sundhedsplatformen som værende direkte usagligt. 


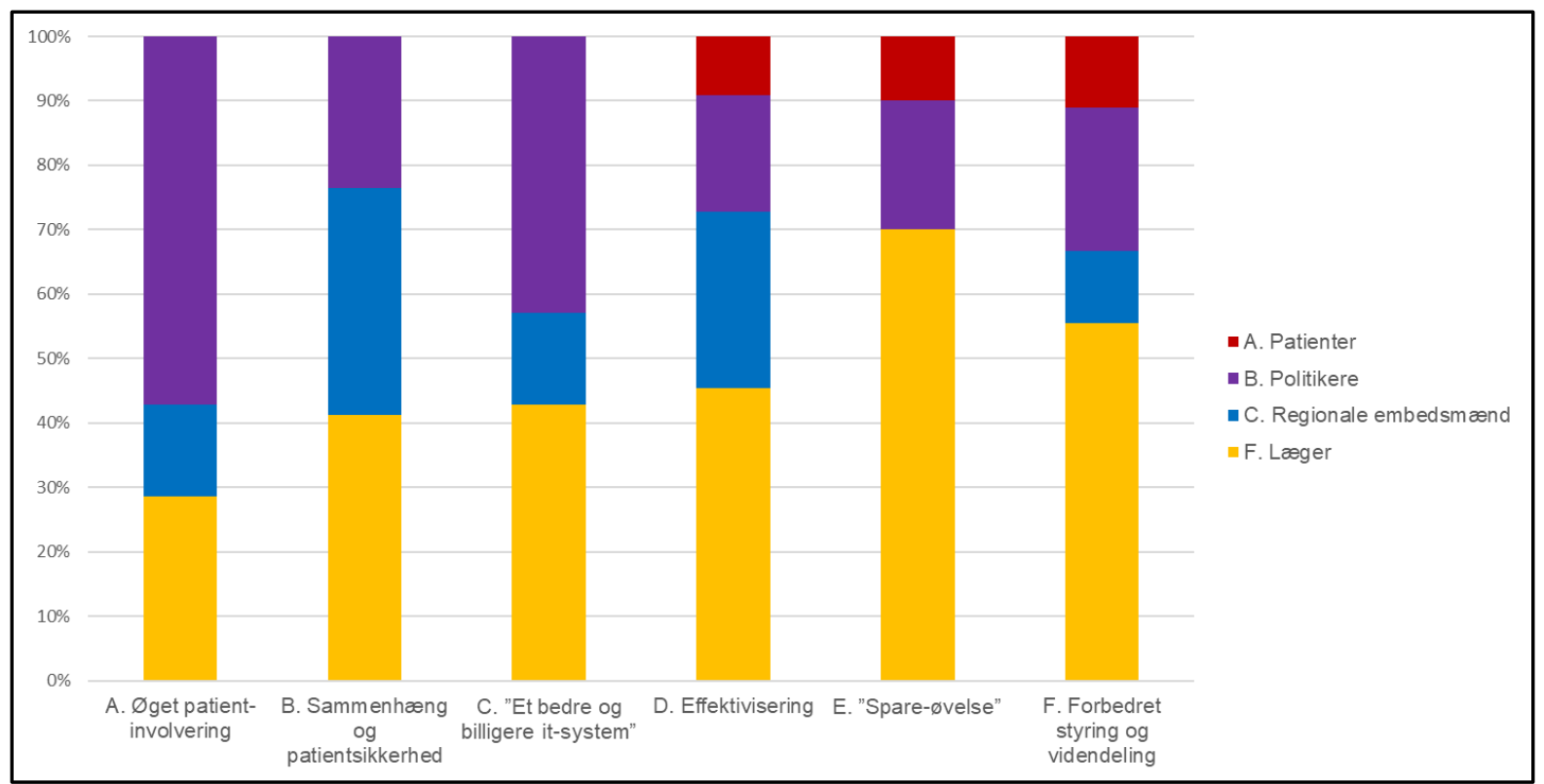

Figur 6: Udsagn ang. Sundhedsplatformens formål fordelt på udvalgte interessentgrupper; lodret akse angiver antal udsagn i procent inden for hver kode $(\mathrm{N}=78)$.

Dykker vi dybere ned i analysen og fokuserer på fire udvalgte interessentgrupper; patienter, politikere, regionale embedsmænd og læger, viser der sig væsentlige forskelle i forståelsen af formålet med Sundhedsplatformen, jf. Figur 6. Politikere er den gruppe, som relativt mest lægger vægt på "Øget patient-involvering" som formål, mens udsagn fra patienter faktisk lægger vægt på andre formål med Sundhedsplatformen end "Øget patient-involvering".

Læger er omvendt den gruppe, som relativt set mest lægger vægt på ”Spare-øvelse”, og dermed ser en ren besparelsesdagsorden som en vigtig årsag til implementeringen af Sundhedsplatformen. Læger er dog også den interessentgruppe, som lægger relativt set mest vægt på ”Forbedret styring og videndeling” - måske fordi læger håber, at den dimension af Sundhedsplatformen vil forbedre deres muligheder for at helbrede patienter. Men "Spare-øvelse" fremstår altså som det væsentligste formål, jf. de følgende udsagn:

Sundhedsplatformen er et ikke sarligt velfungerende amerikansk system, som er købt $i$ en sparemodel uden digital diktering og uden, at den er hagtet op på nogen af systemerne $i$ vores laboratorier for eksempel.

(læge, Berlingske Tidende, 10. september 2017)

I øst har man gevinstrealiseret (fyret) en masse lagesekreterer, fordi man har sat lager til at gøre sekreterernes arbejde. 


\section{Syn på anvendelsen: Massiv kritik af Sundhedsplatformen}

Det vil nok ikke komme bag læsere af danske aviser igennem de seneste år, at fremstillingen af anvendelsen af Sundhedsplatformen samlet set domineres af kritiske udsagn. Disse udsagn omfatter vurderinger af Sundhedsplatformen som konkret it-værktøj til brug på de to regioners hospitalsenheder. Som illustreret i Figur 7, er ca. $71 \%$ af de i alt 255 analyserede udsagn om den faktiske anvendelse af platformen negative, mens ca. $6 \%$ er positive. En række udsagn svarende til ca. $21 \%$ er præget af en kombination af positive og negative vurderinger af anvendelsen, mens ganske få udsagn omhandler den faktiske anvendelse af platformen uden at indeholde en positiv eller negativ vurdering (neutral).

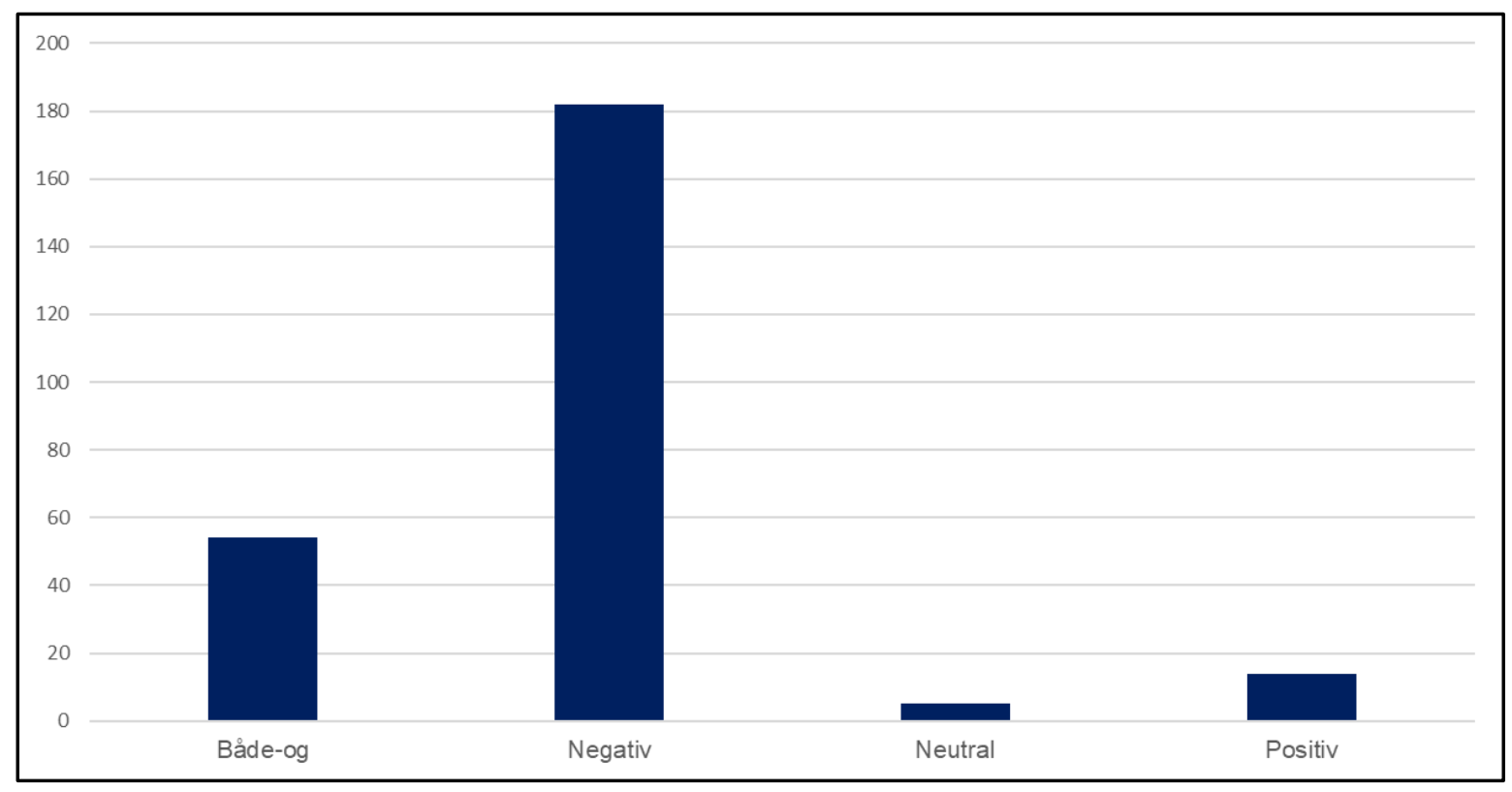

Figur 7: Udsagn ang. anvendelse af Sundhedsplatformen; lodret akse angiver antal udsagn $(N=255)$.

De negative udsagn om brugen af platformen spænder bredt og dækker fx over, at Sundhedsplatformen ses som en tidsrøver, der forstyrrer lægegerningen, at systemet er amerikansk og ikke passer til en dansk hospitals-kontekst samt at der mangler sammenhæng til bl.a. det eksterne, Fælles Medicinkort med dertilhørende risici for patienterne. De negative udmeldinger domineres af lægerne og nogle af de mere markante udsagn lyder som følger:

Ogjeg bliver fortvivlet, når jeg ser den ødelaggende virkning, Sundhedsplatformen har på lagestandens og sundhedspersonalets arbejdsvilkår. For slet ikke at snakke om den langt ringere behandling, patienterne får. Det er så trist. 
Der er ikke tale om børnesygdomme, der er tale om oldingesygdomme, systemet er dement.

(læge, Politiken, 14. november 2017)

Sikke noget lort. Man har brugt flere milliarder på et 40 år gammelt stykke software, som man ikke kan kode $i$, fordi det ikke taler sammen med andre systemer. Det er vanvittigt.

(læge, Jyllands-Posten, 14. april 2018)

Mange lager og plejere på sygehusene i Region Hovedstaden og Sjalland oplever SP

[Sundhedsplatformen] som et så ringe stykke varktoj, at det narmest virker ydmygende at skulle arbejde med det.

(læge, Politiken, 31.juli 2018)

I forsøget på at gøre ting smarte og automatiserede, er der ingen, der har styr på, hvad der faktisk foregår.

(læge, Berlingske Tidende, 20. oktober 2018)

Både individuelle patienter og især patientorganisationer ytrer sig også negativt om platformen.

Fra direktøren i Kræftens Bekæmpelse lyder det fx: "Det er simpelthen ikke $i$ orden. Konsekvensen er, at vi ikke aner, om kraftpatienter bliver undersøgt og behandlet til tiden”. Han peger på, at de forlængede ventetider både forringer helbredelseschancen og giver søvnløse nætter hos patienterne (Politiken, 3. juli 2017).

En nøjere analyse af de (få) positive udsagn viser, at de primært stammer fra de to regioners embedsmænd. En embedsmand fortæller fx, at "Når vi tor tale om effektiviseringer fra Sundhedsplatformen allerede nu, så skyldes det altså, at systemet på nogle områder allerede virker godt, og at det $i$ øorigt hele tiden forbedres.” (Politiken, 22. august 2017). Ser vi isoleret på udsagn fra politikere, er der numerisk flest udsagn, som er negative i forhold til anvendelsen af Sundhedsplatformen, men relativt set er udsagn fra politikere dominerende, når der vægtes både positive og negative aspekter af anvendelsen af Sundhedsplatformen. Måske en forklaring på netop dette forhold skal søges i politikeres traditionelle inklination mod at afveje forskellige interesser. 


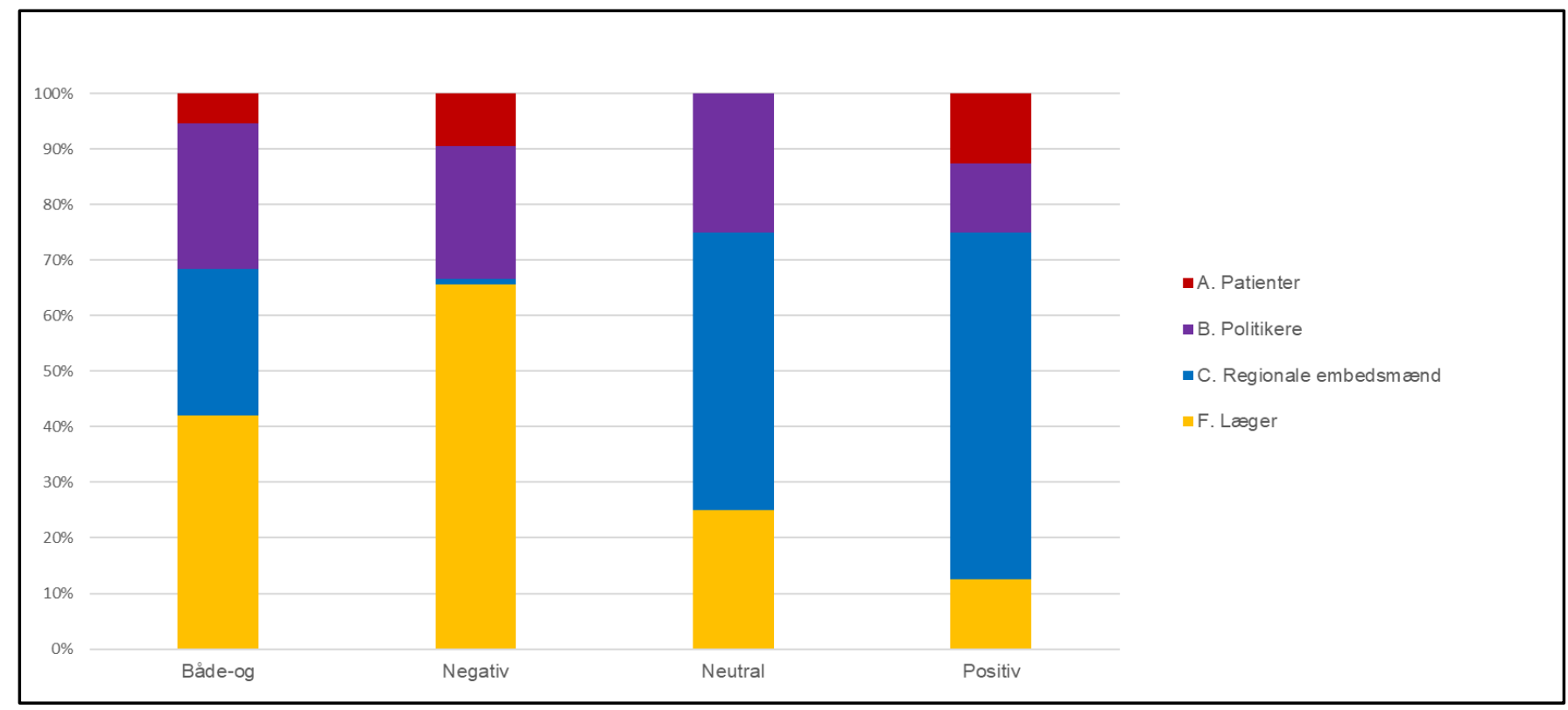

Figur 8: Udsagn ang. anvendelse af Sundhedsplatformen fordelt på udvalgte interessentgrupper; lodret akse angiver antal udsagn i procent $(N=155)$.

Mediernes dækning giver også en kraftig indikation af, hvad den udbredte utilfredshed hos interessenterne skyldes. Som det ses af Tabel 2, viser vores kodning at det i $64 \%$ af de negative og både-og udsagnene, er selve it-løsningen som fremhæves som årsag til problemerne. I 27 \% af de negative og både-og udsagnene angives det af interessenten, at en uhensigtsmæssig implementering af Sundhedsplatformen er årsagen. Der er omvendt kun 1 \% af udsagnene, som angiver brugernes kompetencer mv. som værende årsag til, at Sundhedsplatformen vurderes negativt.

\begin{tabular}{|l|l|l|}
\hline Årsag & Antal & Procent \\
\hline It-løsning & 184 & 64 \\
\hline Implementering & 76 & 27 \\
\hline Regionsledelsen & 23 & 8 \\
\hline Brugerne & 3 & 1 \\
\hline I alt & $\mathbf{2 8 6}$ & $\mathbf{1 0 0}$ \\
\hline
\end{tabular}

Tabel 2: Interessentudsagn, som angiver årsagen til negativ eller både-og vurdering; ét udsagn kan indeholde flere årsager $(N=286)$

\section{Teknologiens grundlæggende natur: Negative teknologi-forståelser dominerer}

Den negative forståelse af Sundhedsplatformen kommer også til udtryk i det vi betegner som interessenternes grundlæggende syn på Sundhedsplatformen som teknologisk løsning. Sådanne 
udsagn er mere abstrakte beskrivelser af interessenternes forståelse og følelser omkring Sundhedsplatformen og sundheds-it mere generelt. Interessenternes synes den grundlæggende natur kan overordnet set opdeles i fem forskellige kategorier, jf. Tabel 1.

Som det fremgår af Figur 9, er det udsagn kodet som ”Fortrænger menneskeligheden” og

”Begrænser arbejdsglæden og stjæler arbejdstiden”, som fremstår mest dominerende. Udsagn, som lægger vægt på teknologi som en nødvendig, uomgængelig og primær positiv del af "Fremtidens hospital", er væsentlig mindre dominerende. Herudover er det værd at bemærke, at et begrænset antal udsagn er præget af en mere pragmatisk, grundlæggende forståelse, som under overskriften "Intet system er fejlfrit” lægger vægt på, at teknologi er et nødvendigt redskab, men sjældent fejlfrit.

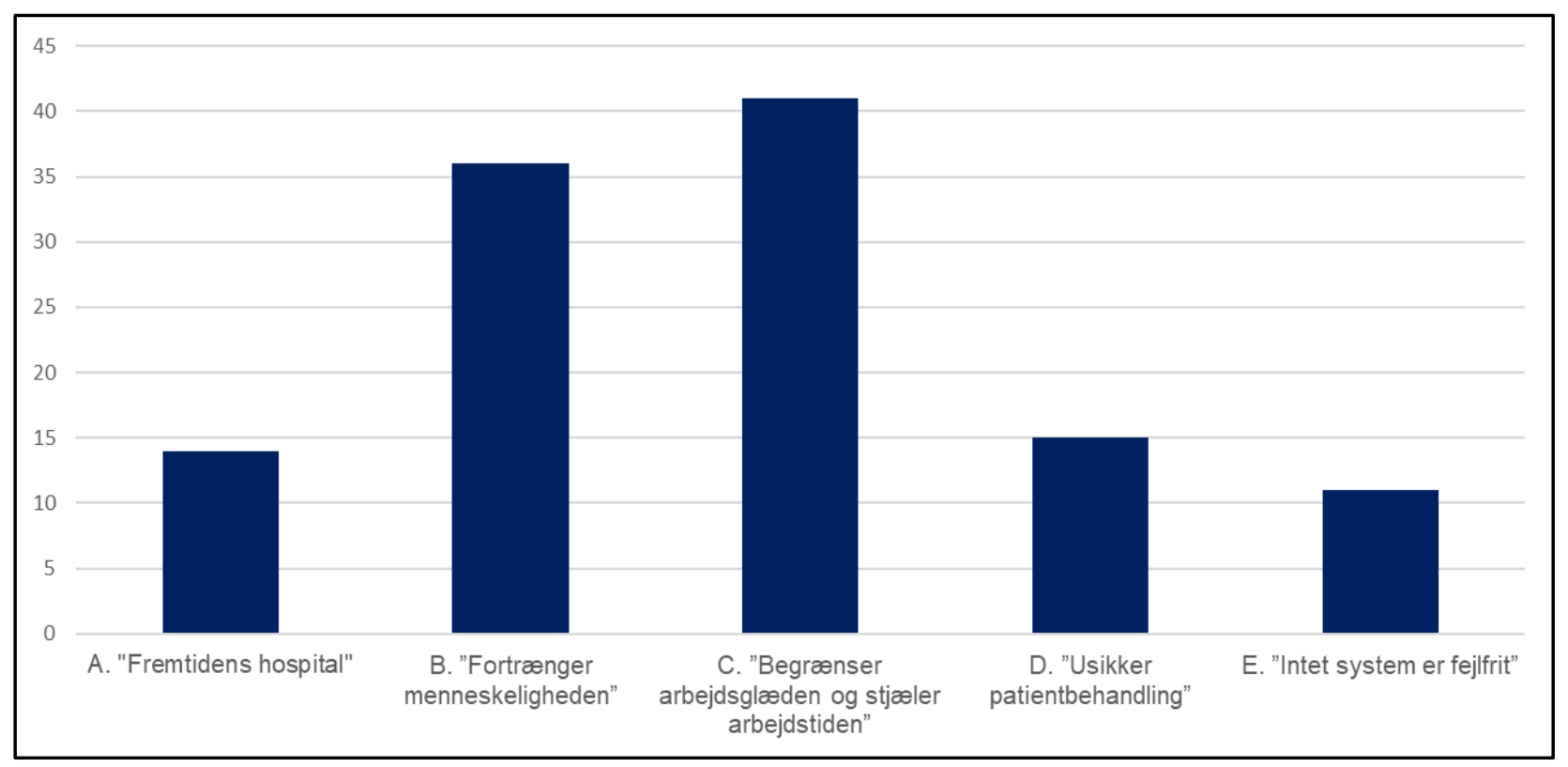

Figur 9: Udsagn ang. grundlaggende syn på teknologi; lodret akse angiver antal udsagn $(N=117)$

I Tabel 3 har vi samlet en række illustrative interessentudsagn, som demonstrerer de væsentlige forskelle i de grundlæggende syn på Sundhedsplatformen. 


\begin{tabular}{|c|c|}
\hline $\begin{array}{l}\text { Grundlæggende syn på } \\
\text { Sundhedsplatformen }\end{array}$ & Illustrative udsagn \\
\hline Fremtidens hospital & $\begin{array}{l}\text { "Sundhedsplatformen er den rigtige losning for fremtidens sundhedsvesen } i \\
\text { Danmark" (embedsmand, Politiken, 2. august 2018). } \\
\text { "Ligesom f.eks. politi, forsvar og banker skal hospitaler kunne kommunikere } \\
\text { hurtigt og sikkert digitalt på kryds og tvars" (politiker, Politiken, 29. august } \\
\text { 2018). }\end{array}$ \\
\hline $\begin{array}{l}\text { Fortrænger } \\
\text { menneskeligheden }\end{array}$ & $\begin{array}{l}\text { "Hvis man ikke vidste bedre, kunne man tro, at computerne var vores patienter, for } \\
\text { det er computerne, der forlanger al vores opmarksomhed. Vi mindes en tid, hvor en } \\
\text { vigtig del af mødet med en patient handlede om omsorg og forståelse for } \\
\text { individet" (læge, Jyllands Posten, 20. juli 2018). } \\
\text { "Lagerne, er usikre på om de gør »som IT-systemet vil have det«. Ikke hvad } \\
\text { patienterne har behov for" (læge, Berlingske Tidende, 20. oktober 2018). }\end{array}$ \\
\hline Begrænser arbejdsglæden & $\begin{array}{l}\text { "[Sundhedsplatformen] stjaler vores arbejdstid og berøver os vores arbejdsglede" } \\
\text { (læge, Politiken, 11. september 2018). } \\
\text { "Arbejdsgladen er totalt forsvundet, vi foler os som marionetdukker, som fores } \\
\text { rundt i Sundhedsplatformen af superbrugerne, vores marionetforere, og vi frygter } \\
\text { hele tiden at overse noget, som kan fä fatale konsekvenser for patienterne." (læge, } \\
\text { Politiken, 16. december 2017). }\end{array}$ \\
\hline $\begin{array}{l}\text { Usikker } \\
\text { patientbehandling }\end{array}$ & $\begin{array}{l}\text { "Det kan ikke betegnes som patientsikkert, at et dysfunktionelt computerprogram } \\
\text { endrer min ordination" (læge, Politiken, 16. januar 2018). } \\
\text { "Det er endnu et eksempel på, at IT-systemet truer patientsikkerheden" } \\
\text { (repræsentant for patientorganisation, Berlingske Tidende, 22. januar } \\
2018 \text { ). }\end{array}$ \\
\hline Intet system er fejlfrit & $\begin{array}{l}\text { "Vil der fortsat ske fejl? Ja - det gjorde der for SP [Sundhedsplatformen], og det } \\
\text { vil der også gore fremover, på et hospital med hundredtusindvis af årlige } \\
\text { patientkontakter" (læger, Politiken, 21. maj 2017,). }\end{array}$ \\
\hline
\end{tabular}




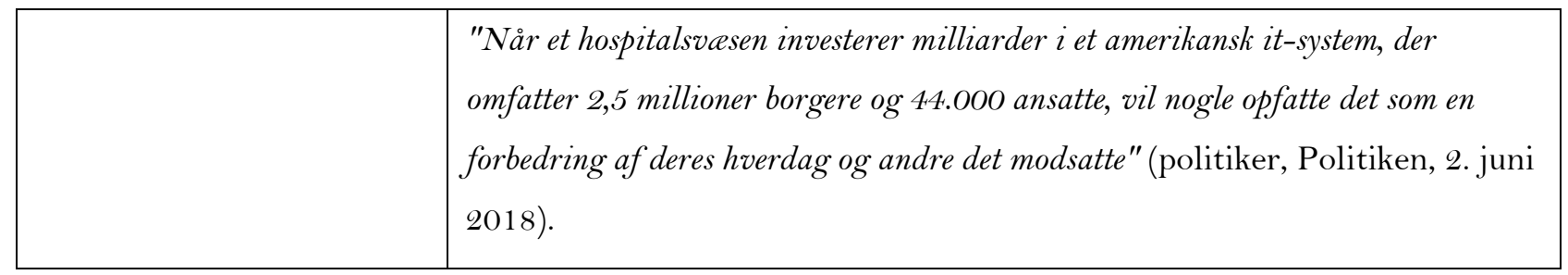

Tabel 3: Interessantudsagn om grundlaggende syn på Sundhedsplatformen.

Ligesom i beskrivelsen af de andre typer udsagn er det interessant at dykke dybere ned i analysen og fokusere på de fire udvalgte interessentgrupper, jf. Figur 10. Her er det tydeligt, at udsagn fra læger relativt set tydeligst udtrykker en markant, negativ forståelse af Sundhedsplatformen, som "Fortrænger menneskeligheden” og ”Begrænser arbejdsglæden og stjæler arbejdstiden”. Udsagn fra patienter udtrykker - ikke overraskende - en optagethed af "Usikker patientbehandling", men også det menneskelige aspekt i behandling i form af "Fortrænger menneskeligheden”.

Omvendt er udsagn fra politikere mere værdiladede i form af både det primært positive, "Fremtidens hospital", og det tydeligt negative, "Fortrænger menneskeligheden”. Endelig er udsagn fra embedsmænd mest dominerende ift. den nævnte, mere pragmatiske forståelse af teknologi som nødvendig, men sjældent fejlfrit.

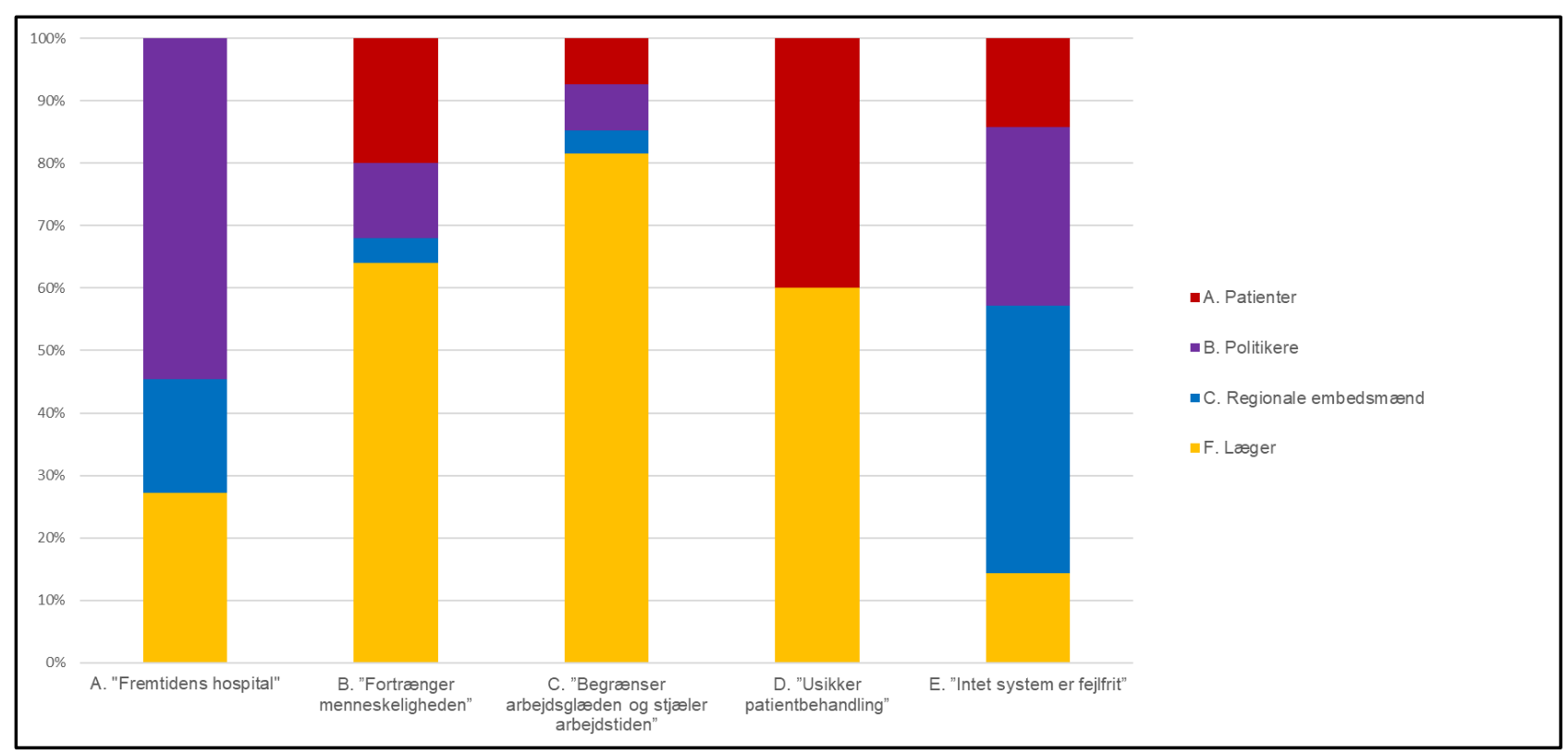

Figur 10: Udsagn ang. grundlaggende syn på teknologi fordelt på udvalgte interessentgrupper; lodret akse angiver antal udsagn i procent inden for hver kode $(N=80)$ 


\section{E. Diskussion og konklusion}

Denne artikel udgør den første større videnskabelige analyse af Sundhedsplatformen i Region Hovedstaden og Region Sjælland, som er et af de mest omdiskuterede offentlige digitaliseringsinitiativer i de senere år. Vi har kortlagt omtalen af platformen i toneangivende medier (1. juli 2012 - 31. dec. 2018) med særlig fokus på de forskellige interessenters opfattelser og bagvedliggende forståelser af Sundhedsplatformen.

Vores analyse tegner et billede af en debat om et omfattende offentligt digitaliseringsinitiativ, hvor kritiske udsagn er tydeligt fremherskende. Samtidig viser analysen, at debatten om Sundhedsplatformen har været præget af en skævhed i hvilke interessenter, som er kommet til orde. Det er hovedsageligt lægerne, som har domineret debatten, og som er gået forrest i den til tider meget kraftige kritik. Analysen bekræfter således, at der ofte eksisterer en skævhed i forhold til hvilke interessenter, der kommer til orde i offentlige debatter.

Baseret på Orlikowskis \& Gashs (1994) typologi for teknologiske forståelsesrammer, er debatten præget af en vis mangfoldighed i forståelsen af formålet med Sundhedsplatformen, hvor der lægges vægt på elementer som øget patientinvolvering, mere sammenhængende it-systemer og bedre videndeling, som udtrykkes vis-a-vis en forståelse af formålet med platformen som blot værende en 'spare-øvelse'. En del af forklaringen på den massive kritik af Sundhedsplatformen skal formodentlig søges i de store forskelle i interessenternes grundlaggende syn på Sundhedsplatformen, som kommer til udtryk. Disse udsagn er - særlig blandt læger - præget af en stærk forståelse af, at Sundhedsplatformen begrænser arbejdsglæden, medfører usikker patientbehandling og fortrænger menneskeligheden i mødet mellem patient og personale. Det ligger formodentlig uden for enhver diskussion, at baggrunden for forskellene i de grundlæggende syn bl.a. kan relateres til forståelser af magt, status, samarbejdsrelationer mv. på de berørte hospitaler og institutioner - forståelser som vores analyse dog ikke har belyst. For så vidt angår synet på den konkrete anvendelse af Sundhedsplatformen er ca. 70 \% af udsagnene negative, og vores analyse viser, at det er selve it-løsningen - og i mindre grad implementeringen og brugernes kompetencer - som fremhæves som årsag til den udbredte utilfredshed hos interessenterne.

Som nævnt er der desuden en kraftig skævhed i debatten: Læger - og i væsentlig mere begrænset omfang politikere og regionale embedsmænd - fylder i debatten, mens det modsatte gør sig gældende for øvrigt sundhedspersonale (sygeplejersker, lægesekretærer mv.) og it-leverandører. 
Uden at vores data forklarer denne skævhed, kan det overvejes, om den delvis skyldes ubevidste opfattelser af høj- og lavstatus-professioner blandt journalister og redaktører, eller den primært skyldes forskel i interessenternes evne og lyst til at udtale sig og deltage i debatten. Endelig er det værd at notere, at journalister og aviskommentatorer er ansvarlige for ca. $10 \%$ af de analyserede udsagn, hvoraf én individuel kommentator er afsender på ca. $5 \%$ af samtlige udsagn, og dermed ikke blot er betydende for vinkling mv. af artiklerne, men også er en central, direkte stemme i debatten. Samlet set demonstrerer undersøgelsen således, at der på det undersøgte område er et stykke til et traditionelt ideal om en oplysende og pluralistisk mediedækning, idet det er sandsynligt, at både andre personalegrupper i sundhedssektoren og tekniske eksperter vil udtrykke delvist andre opfattelser og forståelser.

Da journalister og redaktører - via beslutninger om emner, og hvordan emnerne beskrives - ikke alene gengiver omverdenen, men også deltager i skabelsen af dagsordener, tegner analysen samtidig et billede af, hvilke "vinkler" om Sundhedsplatformen, som de analyserede medier har prioriteret. Analysen giver dog på ingen måde anledning til at tro, at journalister og redaktører er alene om at sætte dagsordenen for hvad der bringes i medierne: I stedet er der grund til at tro, at også mediedækningen af Sundhedsplatformen løbende "forhandles" mellem en række forskellige interessenter, som er kendetegnet af hver deres interesser, profilerings-behov og evner til at formulere synspunkter med udgangspunkt i de oplevelser, som egner sig til mediernes skabeloner for formidling (Lund, 1997).

\section{Bidrag til praksis}

Vores indgående analyse af mediedebatten bekræfter i det store og hele det billede af Sundhedsplatformen, som mange almindelige læsere formodentlig vil kunne genkende: Et omdiskuteret og stærkt kritiseret digitaliseringsinitiativ. Alligevel er analysen interessent også i praksis, idet den for det første bidrager til at sætte spørgsmålstegn ved, om Sundhedsplatformen overhovedet på sigt vil blive en succes ligegyldig, hvordan systemmæssige og organisatoriske forhold omkring brugen af platformen håndteres af de to regioner i fremtiden. Det skyldes to forhold: Analysen viser, at kritikken af den konkrete anvendelse - i hvert fald i medierne - er baseret på negative vurderinger af grundlæggende forhold ved selve it-løsningen, og kun i mindre grad af implementeringen af platformen og forhold omkring brugerne (uddannelse, kompetencer mv.). Herudover er stærkt negative, grundlæggende syn på Sundhedsplatformen udbredte blandt særlig lægerne, hvilket kan forventes at forme disses konkrete holdninger og handlinger i relation 
til brug af platformen tilsvarende negativt på trods af eventuelle konkrete systemmæssige forbedringer (Orlikowski \& Gash, 1994).

For det andet er der en lære for både lægeprofessionen og andet sundhedsfagligt personale i de to regioner: Som vi viser, har der været tale om en markant skævhed i debatten, hvilket må formodes at give et mindre nuanceret billede af anvendelsen af Sundhedsplatformen end hvis flere faggrupper som fx sygeplejersker, lægesekretærer og laboranter var kommet tilsvarende til orde. Det medfører en risiko for, at fremtidige, konkrete beslutninger om anvendelse af Sundhedsplatformen på de enkelte hospitaler og afdelinger ikke træffes på et bredere tværfagligt grundlag, men primært baseres på monofaglige, grundlæggende forståelser blandt lægerne.

For det tredje og på et mere generelt plan bidrager undersøgelse med viden om, hvordan indførelse af digital teknologi i store, offentlige organisationer, som fx hospitalsvæsenet, kan blive et omdrejningspunkt i medierne. Her er således en lære for ledelsen af og arbejdet med implementeringer af it-systemer i offentlige organisationer, der som i sundhedsvæsenet er præget af veludviklede professionsfagligheder som læger og sygeplejersker. Vores analyse illustrerer både, hvordan nogle professioner har bedre adgang til medierne end andre, og samtidig hvor stærke, negative syn på teknologiens grundlæggende natur, implementeringen af omfattende systemer som Sundhedsplatformen med tilhørende ændringer i arbejdsgange mv. i hvert fald i visse tilfælde kan bidrage til at fremkalde. Uden at vores analyse dokumenterer det, er det en plausibel antagelse, at en så omfattende mediedækning, som der i tilfældet Sundhedsplatformen har været tale om, medfører et feedback til brugernes opfattelse og dermed anvendelse af itsystemet, hvilket nødvendiggør, at man som led i implementeringen af it-systemet aktivt søger at forstå brugernes grundlæggende syn på teknologi, og hvordan dette kan forventes at påvirke mediedebatten.

\section{Fremtidig forskning}

Mens vi i denne artikel har fokuseret på de opfattelser og forståelser af Sundhedsplatformen, som er kommet til udtryk i medierne, opfordrer vi fremtidige undersøgelser af Sundhedsplatformen til at belyse den direkte anvendelse af systemet på hospitalerne gennem fx dybdegående case studier. Med afsæt i vores analyse vil det her være interessant at belyse, hvordan samspillet mellem individers og gruppers teknologiske grundforståelser af hhv. formål og natur påvirker anvendelsen af Sundhedsplatformen og hvordan grundforståelserne eventuelt ændrer sig over tid. 
I en delvis anden forskningsmæssig retning vil det også være interessant at belyse, hvorvidt medierne selv - primært journalister og redaktører - er præget af særlige teknologiske forståelsesrammer. I en verden i stadig teknologisk forandring er det vores forudsigelse, at det ikke er sidste gang, at et stort offentligt digitaliseringsinitiativ gøres til genstand for en omfattende mediedebat, hvorfor mediernes medierende rolle er relevant at belyse også på dette felt.

Endelig, og fordi vores undersøgelse sluttede med udgangen af 2018, vil det også være interessent at undersøge udviklingen i debatten efter dette tidspunkt, i takt med at Sundhedsplatformen formodentlig modnes og videreudvikles, og arbejdsgange og vaner blandt personale tilpasses platformen yderligere. Det vil herunder også være interessant at kaste lys over, om de stærkt negative forståelser af Sundhedsplatformens grundlæggende natur, som vi har dokumenteret i debatten, påvirkes af en evt. stigende tilfredshed i anvendelsen af Sundhedsplatformen over de næste år.

\section{Referencer}

Bernard, H. R., Wutich, A. \& Ryan, G. W. (2017): Analyzing Qualitative Data: Systematic Approaches, Los Angeles, Sage.

Bossen, C. (2018): Next Generation Healthcare Infrastructures: Firing, Hiring and Reskilling Staff, paper for Workshop on Next Generation of Electronic Health Records, Copenhagen, March 21.

Brorholt, G. (2016): 'Sundhedsplatformen: Et værktøj til at inddrage patienterne?' in Tidsskrift for Dansk Sundhedsvasen, 92 (8): 10-16.

Carvalho, J. V., Rocha, Á., \& Abreu, A. (2016): 'Maturity Models of Healthcare Information Systems and Technologies: a Literature Review' in Journal of Medical Systems, 40 (6): 1-10. https://doi.org/10.1007/s10916-016-0486-5

Clayman, S. E., \& Reisner, A. (2017): 'Gatekeeping in Action : Editorial Conferences and Assessments of Newsworthiness' in American Sociological Review, 63 (2): 178-199.

https://doi.org/10.2307/2657322

Ejersbo, N., \& Greve, C. (2016): 'Digital era governance reform and accountability: The case of Denmark' in T. Christensen \& P. Lægreid (eds.): The Routledge Handbook to Accountability and Welfare State Reforms in Europe, London, Routledge: 267-279.

https://doi.org/10.4324/9781315612713

Entman R.M. (1993): 'Framing: Toward Clarification of a Fractured Paradigm' in Journal of Communication, 43 (4): 51-58. https://doi.org/10.1111/j.1460-2466.1993.tb01304.x 
Hjarvard, S. (2015): 'Framing: Introduktion til et begreb og en klassisk tekst' in MedieKultur: Journal of Media and Communication Research, 31 (58): 104-114.

https://doi.org/10.7146/mediekultur.v31i58.20026

Konkurrence- og Forbrugerstyrelsen (2012): Udbudsbekendtgørelse 2012/S 182-298788 ang. Ittjenester: rådgivning, programmeludvikling, internet og support, www.udbud.dk/Pages/Tenders/ShowTender?tenderid=4585\#, tilgået 3. juni 2019

Lauesen, S. (2018): Damage and damage causes in large IT government projects, version 9, IT Universitetet, København, www.itu.dk/people/slauesen/SorenDamages.html

Lund, A. (1997). Smitsomme sygdomme i dansk journalistik: Handlingsaspekter ved sundhedsfaglig formidling anskuet genealogisk i en offentlighedsteoretisk referenceramme. København: Munksgaard. https://doi.org/10.7146/mediekultur.v14i28.1118

Mørck, P., Langhoff, T. O., Christophersen, M., Møller, A. K., \& Bjørn, P. (2018): 'Variations in Oncology Consultations: How Dictation Allows Variations to be Documented in Standardized Ways' in Computer Supported Cooperative Work, 27 (3): 539-568. https://doi.org/10.1007/s10606$\underline{018-9332-2}$

Nielsen, J. A., Mathiassen, L. \& Newell, S. (2014): 'Theorization and Translation in IT Institutionalization: Evidence from Danish Home Care' in MIS Quarterly, 38 (1): 65-86. https://doi.org/10.25300/misq/2014/38.1.08

Nielsen, J.A., Andersen, K.N., \& Sigh, A. (2016): 'Robots conquering local government services: A case study of eldercare in Denmark' in Information Polity, 21 (2): 139-151.

https://doi.org/10.3233/ip-160381

Orlikowski, W. J., \& Gash, D. C. (1994): 'Technological Frames: Making Sense of Information Technology in Organizations' in ACM Transactions on Information Systems, 12 (2): 174-207.

https://doi.org/10.1145/196734.196745

Region Hovedstaden (2015): Region Hovedstadens business case ved Sundhedsplatformen vers. 2,4, bilag 7 til møde i Forretningsudvalget 15. august 2017, dagsorden.regionh.dk/committee_1444/agenda_291942/documents/86633efb-bc13-493e-bf6eof3256e7c769.pdf, tilgået 3. juni 2019

Region Hovedstaden (2016): Sundhedsplatformen i luften, pressemeddelelse, 21 . maj 2016, www.regionh.dk/presse-og-nyt/pressemeddelelser-og-nyheder/Sider/Sundhedsplatformen-iluften.aspx, tilgået 3. juni 2019

Region Hovedstaden (2018): Ny brugerundersøgelse skal forbedre Sundhedsplatformen, pressemeddelelse, 9. april 2018, www.regionh.dk/presse-og-nyt/pressemeddelelser-ognyheder/Sider/Ny-brugerundersoegelse-skal-forbedre-Sundhedsplatformen.aspx, tilgået 3. juni 2019 
Region Hovedstaden (2019a): Fakta om Sundhedsplatformen, www.regionh.dk/tilfagfolk/Sundhed/sundhedsplatformen/om-sundhedsplatformen/Sider/Fakta-omSundhedsplatformen.aspx, tilgået 3. juni 2019. https://doi.org/10.6027/9789289330251-7-da

Region Hovedstaden (2019b): Sundhedsplatformen - fremskridt efter hård omstilling, www.regionh.dk/til-fagfolk/Sundhed/sundhedsplatformen/omsundhedsplatformen/Sider/Sundhedsplatformen-fremskridt-efter-haard-omstilling.aspx, tilgået 3. juni 2019

Region Sjælland (2014): Status for Sundhedsplatformen, bilag 6 til møde i MED-Hovedudvalget 23. juni 2014, www.regionsjaelland.dk/omregionen/job-og-karriere/med-system/moedeplan2014/20140623/Punkt10_bilag6_Status\%20for\%20Sundhedsplatformen.pdf, tilgået 3. juni 2019

Rigsrevisionen (2017): Rigsrevisionens beretning om Sundhedsplatformen afgivet til Folketinget med Statsrevisorernes bemerkninger, beretning nr. 17, København

Schou.J. \& Hjelholt, M. (2019): 'Digitaliseringen af den danske offentlige sektor: hvor er vi på vej hen?’ i Økonomi \&̊ Politik, 92 (2): 33-47.

Simonsen, J., Hertzum, M., \& Scheuer, J. D. (2018): 'Quality Development in Health Care: Participation vs. Accreditation' in Nordic Journal of Working Life Studies, 8 (S3): 49-69. https://doi.org/10.18291/njwls.v8is3.105276

Sundheds- og Aldreministeriet (2017): Orientering om status på udrulning af Sundhedsplatformen til Folketingets Sundheds- og Aldreudvalg, bilagsnr. 123, alm. del, folketingssamling 2017-18, www.ft.dk/samling/20171/almdel/SUU/bilag/123/1832099.pdf, tilgået 3. juni 2019

Young B., Mathiassen L., Davidson E. (2016): 'Inconsistent and Incongruent Frames During IT enabled Change: An Action Research Study into Sales Process Innovation' in Journal of the Association of Information Systems, 17 (7): 495 - 520. https://doi.org/10.17705/1jais.00432

\section{Avisartikler}

Børsen (18. juni 2013): 'Udskilningsløb om én milliard'

Berlingske Tidende (23. december 2016): 'Sundhedsplatform er en god ide'

Berlingske Tidende (10. september 2017): 'Overlæge står frem: Hospitaler er nedsparede og dysfunktionelle'

Berlingske Tidende (22. januar 2018): 'Fejl i Sundhedsplatformen: Kræftsyge børn fik for meget eller for lidt kemo'

Berlingske Tidende (20. oktober 2018): 'Nye problemer med Sundhedsplatformen'

Berlingske Tidende (23. januar 2019): 'Politisk flertal er klar til at droppe Sundhedsplatformen' Computerworld (7. juni 2018): 'Sundhedsplatformen kostede Region Sjælland 700 millioner' Information (8. oktober 2016): 'Ny it må ikke gå ud over patienter' 
Information (22. juni 2018): 'Skandalen om Sundhedsportalen er et studie i ringe planlægning'

Jyllands Posten (3. august 2016): 'Når offentlig it slår ihjel'

Jyllands-Posten (14. april 2018): 'Læge? Nej, så hellere crackpusher eller indbrudstyv'

Jyllands Posten (20. juli 2018): 'Nu gælder det en masse data i computeren - og vupti, ud kommer en klar diagnose'

Politiken (6. januar 2014): ' Vores sundheds-it-systemer kan blive bedre'

Politiken (20. maj 2016): 'Nu bliver det lettere at være patient'

Politiken (21. maj 2017): 'I dag er det Sundhedsplatformens fødselsdag'

Politiken (3. juli 2017): 'Kræftkontrol er brudt sammen'

Politiken (22. august 2017): 'Regionsdirektør: Vi skal tøjle vores udgifter, så vi får mest for pengene'

Politiken (27. oktober 2017): 'Dræbende it truer velfærden'

Politiken (14. november 2017): 'Sundhedsplatformen gør vores patienter til tabere'

Politiken (16. december 2017): 'Sundhedsplatformen er et kæmpe tilbageskridt'

Politiken (16. januar 2018): 'Farlige fejl: Medicinen blev ændret af it-system'

Politiken (2. juni 2018): 'Politisk ansvarlig for sløj platform: Det er ikke godt nok'

Politiken (19. juni 2018): 'Sundhedsplatformen kostede mig mit job'

Politiken (31. juli 2018): 'Drop nu Sundhedsplatformen'

Politiken (2. august 2018): 'Ikke den rette vej at gå'

Politiken (29. august 2018): ' Vi ser fortsat Sundhedsplatformen som løsningen i fremtidens sundhedsvæsen'

Politiken (11. september 2018): 'Politikerne bag Sundhedsplatformen begår hybris'

\footnotetext{
${ }^{1}$ Omfatter også artikler i Børsen Weekend.

${ }^{2}$ Baseret på en indledende afprøvning af forskellige søge-strenge, er der er anvendt følgende søge-streng:

"'Sundhedsplatform*' OR 'Sundhedplatform*' OR ('Epic' AND 'Region') OR ('it-system' AND ('region H' OR 'region sjælland')) OR ('it-platform' AND ('region H' OR 'region sjælland')) OR ('it-løsning' AND ('region H' OR 'region sjælland'))". Det bemærkes, at søgningen resulterer i alt 699 artikler, hvoraf dog alene 652 artikler er at betragte som unikke.

${ }^{3}$ Nature of Technology henviser til hvordan aktørerne grundlæggende opfatter teknologien, herunder dets egnethed og funktion. Technology Strategy refererer til aktørernes forståelse af, hvorfor organisationen har anskaffet teknologien.

Technology in Use omfatter aktørernes forståelse af, hvordan teknologien anvendes og får betydning i daglige rutiner. Det er summen af disse tre kategorier, der er bestemmende for aktørernes teknologiske forståelsesrammer, afspejlende: "what the technology is (nature of technology), why it was introduced (technology strategy), and how it is used to create various changes in work (technology in use)" (Orlikowski \& Gash 1994:184).

${ }^{4}$ Den fulde beskrivelse af samtlige koder kan rekvireres ved henvendelse til artiklens forfattere.

${ }^{5}$ Opdelingen i fire kategorier er inspireret af Nielsen, Mathiassen \& Newell (2014).

${ }_{6}$ Vi retter en stor tak til Stud. Scient. Adm. Rikke Nielsen for hjælp til analysearbejdet.
} 